To appear in Children \& Society

\title{
Grounding childhood (trans)national identities in the everyday
}

Christos Varvantakis, Goldsmiths, University of London

Thalia Dragonas, National and Kapodistrian University of Athens

Nelly Askouni, National and Kapodistrian University of Athens

Sevasti-Melissa Nolas, Goldsmiths, University of London

[Word count: 7984]

\begin{abstract}
This paper engages with the lived and experiential aspects of (trans)national identities in childhood, through the exploration of an ethnographic biography of a Greek-Albanian boy in Athens. Through a grounded ethnographic approach, we examine the ways in which he experiences and negotiates his (trans)national identity. Our analysis demonstrates the everyday subtle and sophisticated understanding of the complexities and contradictions of national identities, and the child's own positioning within that. In conclusion, we suggest that interdisciplinary approaches should be assumed in the study of (trans)national identities in childhood, and ones that are grounded in children's own meaning making of their experiences of such identities.
\end{abstract}

\section{KEYWORDS}

National identity, international childhoods, ethnicity, transnational families, agency 


\section{Introduction}

The paper focuses on the phenomenon of (trans)national identity formation in middle childhood foregrounding the everyday, experiential aspects of that process. Drawing on data from the ERC funded Connectors Study (2014-2019), a comparative multimodal ethnography of the relationship between childhood and public life in three cities (Athens, Hyderabad, London) (Nolas, 2015; Nolas, Varvantakis and Aruldoss, $2016,2017)$, the present paper explores an ethnographic biography of the (trans)national identity practices of one immigrant child living in Athens, Greece. Changes to international patterns of migration, the proliferation of mobile technologies, and more affordable and frequent air travel means that both first and second-generation migrants across a socio-economic spectrum, develop fuller relationships with countries of (parental) origin (Zeitlyn, 2012) giving rise to the phenomenon of transnational families: those families that maintain active ties and often live across a number of national and cultural borderlands (Fechter, 2007; Fechter and Korpela, 2011; Gardner and Mand, 2012; Haikkola, 2011; Katartzi, 2017; Spyrou, 2002; Zeitlyn, 2012; Zeitlyn and Mand, 2012). To date, the study of children's national identities, has focused on the cognitive aspects of that formation (e.g. categorisation, argumentation and beliefs) (cf. Murphy, 2018 in this journal for a review; Barrett, 2005; Barret and Oppenheimer, 2011; Dobson, 2009). Here, national identity formation is conceptualised as an issue of membership, and research tends to explore the ways in which children think about and understand their own and others' belonging to a particular national grouping. There is little reference to the everyday and/or lived experience, either conceptually or methodologically, which 
might also allow us to consider what children $d o$ and how they feel in different situations and across different relationships. The literature on children's national identity formation has also been slow to embrace transnational phenomena. This has led Barrett (2000), a key contributor to this body of knowledge, to describe it as empirical knowledge in search of an integrated developmental theory of the sociocultural and psychological factors which drive national and ethnic identifications. He contends that taking account of a child's internal and external worlds, the layered and dynamic influences between them, and the influences of the media, school, and family on the former, is likely to give researchers a more robust and dynamic understanding of national identity formation in childhood (Barrett, 2000; 2005). Nevertheless, such reflections remain within a sociocognitive orientation and as such, are often limited theoretically and methodologically to an understanding of context as environmental influences which can be untangled into neatly defined variables (e.g. 'the media', 'the school' etc).

In this paper we suggest that the more grounded and situated approach being sought in developmental psychology has much to gain from engaging in an interdisciplinary dialogue with anthropology and the ethnographic method, as well as the sociology of childhood, in which context, everyday life, lived experiences and children's agency are key concerns. We take up the call for more dynamic, interdisciplinary and socio-culturally situated theorising in several ways. Firstly, we contend, in line with developments in the sociology of childhood over the last 20 years ( $c f$. James, Jenks and Prout 1998; Morrow 1999; Pugh 2013; White et al., 2011), that such theoretical articulations need to take children's lived experiences into consideration. The inclusion of 
children's own voices and experiences into theory development, is a powerful tool for disrupting taken for granted understandings of (trans)national identity emergence. We also argue that a more interdisciplinary approach to the study of (trans)national identity formation in childhood, embracing modes of data creation and theory generation typical of anthropological and sociological knowledge practices, is also necessary for a grounded theoretical framework to be realised (Cheney 2007; Scourfield et al., 2006). Finally, we argue that any contemporary theoretical articulation of children's national identity needs to engage with the times and places of children's experiences as well as the changing structural patterns of national belonging (Fox and Miller-Idriss, 2008; Scourfield et al., 2006). To talk of children's relationship to one national culture fails to appreciate the ongoing reconfigurations of geographic, economic and political landscapes in contemporary migrant families' everyday lives. As such, any theoretical understanding of children's (trans)national identities needs to be mindful of their provisional nature (Hall, 1993) and contingency on contemporary macro geopolitical structures.

This paper contributes a grounded understanding of the ways in which children's identities emerge against a backdrop of transnationalism (Dobson, 2009). It explores the stories children tell themselves and others about their place in the transnational social field and the strategies they use as they reflect on issues related to identity and belonging. Working through a single ethnographic biography of a second-generation Albanian child living in Athens, and drawing on the insights from the sociology of childhood which emphasizes children's agency in identity construction and active meaning making practices, the analysis highlights how children draw and redraw discursive boundaries 
and connections between self and other through what they say, as well as what they do and feel. We maintain that these playful movements and creative struggles can offer invaluable insights into the subjective aspects of the processes of negotiation and (trans)national identity construction in a rapidly reconfiguring world.

\section{Method: Researching the Relationship between Childhood and Public}

\section{Life}

The ERC funded Connectors Study is an international ethnography which follows 45 6to 8-year-olds, and their families, living in different areas in three cities (Athens, Hyderabad and London). Multimodal ethnography (Dicks, Soyinka and Coffey, 2006) was used in developing the child biographies and family histories. As well as participantobservation in everyday family life, discussions and informal interviews, a range of other methods were also used to explore children's life-worlds: playing (introduced by the children in the study), photography, neighbourhood tours and drawing of maps, mapping of significant relationships, biographical interviews (children and parents) and children's creative workshops (Nolas and Varvantakis, under review; $c f$. Christiansen and Prout, 2005; LeVine, 2007; Pink, 2006; Punch, 2012). The initial ethnographic fieldwork with children and their families took place between October 2014 and May 2016. In this paper, we focus on data emerging from participant observation and from discussions and interviews with the child, as well as with his parents.

The Connectors Study conceptualises encounters, experiences, and engagements with public life in childhood as socio-cultural, sensory, and embodied practices. The 
research design is informed by sociologies of value (Flyvbjerg, 2001; Sayer, 2010; Lutz, 2017) which, through the metaphor of 'what matters', created a common language with our young interlocutors and a means for finding out about the things that were important to them in their everyday lives.

For the present article we focus on a single ethnographic biography of a secondgeneration migrant child from the Athens sample to present a detailed analysis of how this child practices identification, resistance, negotiation, and belongingness in the transnational social field he navigates in his everyday life. There is a long tradition in ethnographic research (e.g. Behar, 1993; Hertzfeld, 1998; Whyte, 1943) and sociological longitudinal research ( $c f$. Nielsen, 2016, this journal) of using single biographies to study social worlds. Cases and examples support learning about social phenomena without foregoing their richness and ambiguity (Flyvbjerg, 2001:66-87), and biographies foreground the 'mutually arising and contrapuntal aspects of our continually shifting sense of ourselves as being both uniquely a 'you' or a 'me', and member of the same class or culture' (Jackson, 2008:380). In focusing on the thick descriptions of a single biography, we aim to demonstrate the level of complexity involved in transnational identity formation processes and practices.

Ardian, a 7-year old boy whose experiences are analysed in this paper, belongs to what Gardner (2012) calls ‘transnational communities' or 'transnational families'. She coins these terms to describe children and their families who participate in social and economic networks which traverse national borders, linking places through a range of practices such as, for example, living in settled communities with an established 
homeland elsewhere or being part of families and communities in which migration abroad is an established way of life (see also Cena, Heim and Trandafoiu, 2018). Ardian's case fits this profile. Ardian is not a migrant himself but he is a child of migrants constituting a transnational family. Moreover, the complex trajectories of transnational families and their articulation within transnational narratives and practices of identity, are better grasped if we were to think of place of origin and place of settlement as intricately interlaced rather than disconnected social spaces. Indeed, as Cena and colleagues' (2018) research demonstrates places of origin and settlement can also be reversed as in the case of children of return migrants in Albania. Thus, a more viable concept is that of 'transnational social fields', with their embedded and intersecting practices, identities and power relations (Zeitlyn, 2012).

Returning to Ardian now, Ardian was born in Greece to immigrant parents from Albania and lives in a working-class neighbourhood in central Athens. The area in which the family lives has a high concentration of immigrants who began moving there in the late 2000s. The change in local demographics has generated reactions from some local Greek residents and, consequently, the area has become fertile ground for the penetration of far-right organizations, on occasion resulting in violent clashes between locals and migrants. Ardian's parents are largely unemployed and struggle financially. Ardian is an emblematic choice for analysis. His is a case of (trans)national childhood, though not an especially exceptional or unusual one, allowing us to focus on Ardian's lived experience and everyday practices of identity formation instead of being distracted by some extraordinary aspect of his or his family's life. Our analysis of Ardian's case pays close 
attention to his 'ecological niche' (Bronfenbrenner, 1979) exploring experiences and feelings of belonging, relationships with significant others in his life, meanings and practices of place, and the ways in which Ardian places himself within the political, national and social context he navigates daily, as well as the ways he handles tensions of identity. The analysis we attempt in this paper, and its organisation, is informed by theories of everyday life (de Certeau, 1984). As such, we have situated our analysis of Ardian's biography around three axes of the everyday life: people, places, and time. In so doing, our analysis draws attention to the relational, spatial and temporal aspects of Adrian's identity formation practices. As characteristic of ethnographic analysis, our understanding of Adrian's case has also been shaped in conversation with him and his family over repeated visits.

\section{Locating the (Trans)National Child}

Transnational childhoods tend to be ignored in the literature on migration (Zeitlyn and Mand, 2012) leading to critiques. For instance, Gardner (2012) has remarked that: 'research on children is important not just because children are, in themselves, a largely ignored group, but also because, once efforts have been taken to see the world through their eyes, much might be learnt about the nature of cultural identity, human mobility and the complex and ever-changing interconnections, exchanges and hierarchies that constitute the global order' (pp. 891-2). Gardner exemplifies how research on transnational childhoods would not only enrich our understanding of children's 
experiences of migration and transnational living, it would also enhance our very understandings of the complexities of these phenomena themselves.

On close inspection we find children are active in the invention of culture rather than simply passive recipients of adult cultures (Hirschfeld, 2002); they are in fact engaged in complex processes of making sense of their national belonging and are in intricate, and often playful, negotiations of that belonging. The work of Hall (1995) is an example of this: Hall has demonstrated how children manage demands made to them by 'home culture' through family, while also managing demands made by the host culture through school and locale. She has shown how children mask parts of their identities to different degrees according to context - i.e. masking completely Sikh identities to achieve academically at school or being 'cautiously English' at the shopping mall, aware that members of their communities might see them but also aware that the host culture marginalizes difference (1995:250). Similarly, Spyrou (2002), in his research with Greek Cypriot children, has demonstrated how children negotiate national stereotypes, and how ethnic categories (such as, 'the Turks') are being used by children in much more complex ways, beyond common-sense national and evaluative connotations ( $c f$. Fox and MillerIdriss, 2008; Leonard, 2012; Mertan, 2011). Such studies highlight the risks of ignoring children's experiences of transnationalism ( $c f$. Pugh, 2013) and the dividends for extending theoretical understandings of the complex processes of (trans)national belonging over time and in different places.

While there has been some interest in the Albanian youth's diasporic identities (Athanasopoulou, 2013; Cena et al., 2018; Michail and Christou, 2016; Katartzi, 2017) in 
the literature, there is a dearth of research on children's (trans)national identities in Greece, a curious omission given the scale of Albanian migration to Greece over the last 30 years. Research among Albanian children and families could potentially enhance theoretical conceptualisations of national and transnational identity formation processes in Greece and beyond, because of what is known about their practices of assimilation. Often Albanian migrants aspire to settle and fit into Greek society as a family; they play down differences and resort to assimilatory practices that silence their otherness, such as name changing and christening children (Triandafyllidou and Kokkali, 2010). Such assimilatory practices can also make readjustment to life back in Albania, for those whose parents decide to return, challenging; a challenge that is spatially and temporally mediated (Cena et al., 2018).

The analysis of Ardian's transnational identity is set against the backdrop of difficult economic and sociocultural times as Greece goes through a period of economic recession and the challenge of accommodating 'otherness' ( $c f$. Adamczyk, 2016). Additionally, it occurs in a national setting where diversity has been marginalised in public narratives of belonging. Dominant nationalist discourses present an understanding of Greece as a homogeneous, mono-ethnic, mono-cultural and mono-religious society, glossing over regional, nomadic, linguistic and borderland identities (Dragonas, 2013).

The wave of migration in the 1990s following the fall of the Berlin wall, resulted in migrants accounting for more than 10 percent of the total Greek population in less than ten years and challenged Greek society, placing multiculturalism on the public agenda (Adamczyk, 2016). Greece having historically been a country of emigration was forced to 
rethink itself as a country of immigration. Despite the rapid change in the cultural composition of the Greek population, Greek society remained largely monocultural in its orientation (Frangoudaki and Dragonas, 1997; Dragonas, 2013, 2014). Racist and nationalist discourses were raised and are further exacerbated all the more as social problems and downward mobility increase owing to the economic and political crisis. In the person of the immigrant, nationalist and xenophobic ideology has found its preferential adversary, and violence towards the 'unwanted others' has become naturalized (Dragonas, 2013).

\section{Ardian, an ethnographic biography}

Ardian's family emigrated from Albania to Greece 15 years ago. Adrian's father works as a construction worker and his mother as a cleaner but in the last six years they have both faced repeated periods of unemployment. Christos, the researcher, regularly met Ardian and his family over a period of 18 months during the first phase of fieldwork. During his visits to the family, Ardian and Christos had conversations about the things that were important to Ardian, they took pictures, drew and made maps of the local area, played, read, discussed and went for walks around Ardian's neighbourhood. In what follows we explore Ardian's relational, spatial and temporal practices of identity formation.

\section{Populating transnational identities}

Ardian draws his cultural references from the persons that dominate his social relationships such as his family and relatives, as well as his teachers and classmates in 
school (cf. Benei, 2008). The latter, as a key institution in the reproduction of national consciousness, transmits Greek language and culture, promotes the dominant values, and cultivates Greek identity. It is very telling that Ardian regularly over the 18 months of fieldwork reproduced a dominant ideology regarding Greek antiquity. This included proclamations about his admiration of the 'ancient Greek language' and an espoused desire to be able to speak it: 'it would be great to speak it one day'. His comment suggests an acute atunement with an important discourse exalting ancient Greek heritage that is often invoked as a marker of legitimate Greek identity. It is a discourse that cuts across most political allegiances including, most problematically, with those of the far right (cf. Kyriazi, 2016).

Certainly, the school curriculum is not transmitted uniformly to all students, neither is it impartial vis-à-vis students' individual, social and ethnic characteristics. Yet, contrary to the monocultural orientation of the Greek schooling system, the classroom composition in Ardian's school is multicultural. In talking to Christos about his friends he mentioned nine names from which only two sounded as if of Greek origin. In these conversations, Adrian himself did not appear to recognize which names were Greek and was not particularly concerned with his friends' ethnicities. His accounts suggest that his social skills have developed in an ethnically heterogeneous group and he talks about friendship as a relation of concern and affection while also identifying with 'others' who are bullied. For example, Ardian talked about a group of Afghan migrants who had settled next to the schoolyard and he reproached those children that made fun of them by telling them that this is 'annoying for these people'. He also spoke about an Egyptian girl 
at school who pushed and swore at other children and an Egyptian boy that he sympathized with because he could not speak Greek and so was picked on by the other children. He described an incident of an Indian woman who he saw begging and the pity this aroused in him and as well as his frustration at having no money to give her. Also, he knows that Muslims do not eat pork while others (whom he could not name) 'do not eat red meat'. Overall, the impression he gave Christos over 18-months of fieldwork, was that he identified with those discriminated against and kept his distance from their persecutors.

When not in school Ardian recounted socializing with members of his immediate or extended family of Albanian origin. In the transnational family sphere Albanian identity practices dominate, for example through language and cooking ( $c f$. Chatzidaki and Maligkoudi, 2013; Gogonas, 2009). Ardian's family socialised predominantly with relatives and fellow Albanians speaking Albanian at home. Several of Ardian's relatives live nearby and share in his family's everyday practices, such as cooking and eating together. Ardian and his brother spend a lot of their time with their cousins, one of which is in the same class at school. He described him as a 'very good friend'. Ardian's extended family, and the support it provides, repeatedly feature in his accounts, giving a clear sense of the ways in which close family ties support processes of identity negotiation and belonging in a foreign culture and society.

\section{Placing transnational identities}


Ardian negotiates his belonging through recourse to three distinctive places, each featuring extensively in his narrative: the immediate environment of his neighbourhood, the more distant historical centre of Athens, and his village in Albania where Ardian spends his summer holidays.

There are several tensions across Ardian's narratives of everyday life and how he relates with his neighbourhood: familiarity and identification feature in his accounts of everyday life yet so do negative feelings and a sense of threat. For instance, although Ardian mentioned a number of examples of 'dangerous things' outside (such as the dirtyold house, the people who are sick or those who get drunk and scream, the noise), he would always gladly go for a walk around his neighbourhood with Christos. In such walks, Ardian demonstrated a great familiarity with the surrounding streets and was eager to show and talk about his favourite places with Christos. His positive evaluation of his neighbourhood extended beyond his immediate social context, such as his school or his cousin's house, to include aspects of surrounding public spaces such as a busy street or the 'round buildings' (art nouveau architecture) which he reported liking more compared to the prevalent 'square' apartment blocks.

Yet alongside these positive evaluations of his neighbourhood Ardian also communicates more troubled ones. He perceives the neighbourhood as stressful and a dangerous place, dusty and noisy with lots of 'sick' and aggressive people. This negative evaluation referred both directly and indirectly to the ethnic and social composition of the neighbourhood's inhabitants. In one of the conversations he had with Christos he spoke about the 'gypsies' who came to the neighbourhood and created problems such as 
dirtying and stealing. He likes the playground near his house, but he is forbidden, by his father, to visit it as this playground has become a contested zone between migrants and members of the far-right in the area. Asked by Christos about the playground and his access to it, he says: 'I think there are problems there now', and at a later instance adds that ' 'bad guys' go there, violent guys'. When probed further on the nature of those problems, Ardian claims not to know any more than what he's told Christos.

Moving further afield, his references to Athens's historical city centre are very positive, at the same time as revealing the limitations of his family's socio-economic status. He recounts to Christos his many visits to the area around the Acropolis, he describes the area as 'it's really nice' because he can see (replicas of) ancient pots or the Acropolis or Athena's temple. Yet entrance to the Acropolis archaeological site is so expensive that Ardian is prevented from fully enjoying the ruins ( $c f$. Varvantakis, manuscript in preparation). He contrasts himself with the rich tourists and identifies with 'the Greeks' who he believes should be able to visit the site at a reduced rate.

Finally, the third place Ardian identifies with is his village in Albania where he spends his summer holidays. He talked very positively of his parental home village and, as he says, 'he dreams of this place sometimes'. Ardian seems to really enjoy the peaceful country life where he is allowed to be outside and 'he can get goat's milk everywhere'. Ardian tells Christos that he has a strong preference for goat's milk, which he considers superior to cow's milk. Yet, in Athens 'it is more expensive because it is scarce', he says. The relationship between food and national belonging is well documented (Sutton, 2010; Yiakoumaki, 2006) and goat's milk, in Adrian's musings about his village, represents 
something beyond nourishment. It has a symbolic meaning and acts as a gesture of connection and belonging to family and country. Foods from one's culture and one's family often become the comfort foods sought in difficult times. Through repeated conversations on the topic, it becomes evident that Ardian associated goat's milk with the meaningful experience of happy summers in his village in Albania. Goats milk represents a bond with his family and his homeland, and in so doing acquires a special value for him. It is what Levitt and Glick Schiller (2004) describe as transnational ways of belonging, a practice of combining actions and symbols intended to demonstrate affiliation and group membership, including transnationally.

\section{Places, people and identities in precarious economic times}

The economic crisis in Greece and elsewhere saw a rise in unemployment, and youth unemployment specifically, a return trend of emigration, and in the case of migrants a further precaritization of the labour market' (cf. Mattoni \& Vogiatzoglou, 2014; Tilly, 2011.). Economic precarity may threaten individual and group identities. For example, in an interview with Stefan, Ardian's father, we find him attributing his unemployment to the labour practices of 'the newly arrived immigrants' who are prepared to work 'ten or twelve hours a day, want no insurance and don't care about security measures'; he, on the other hand, declares that he never works 'black'. In comparing himself with the newly arrived immigrants from Pakistan and other Asian or African countries, with their Muslim religion, 'diseases', 'dirty', and overcrowded living conditions, Stefan demonstrates practices of managing his own threatened identity in the face of ongoing 
discrimination as a first-generation Albanian migrant. Furthermore, in a protective symbolic gesture towards his family's next generation, Stefan argues that his children 'are Greek, they have been brought up and go to school in Greece'. His children 'are also Albanian, of course'. The positive value he ascribes to his children's hybrid Greek and Albanian cultural identities minimises any negativity associated with being Albanian alone. At the same time, differences in religious belief between nationals of each country are omitted from the narrative while the shared racial identification (white European) implied therein offers a further way of distancing himself and his family from newly arrived migrants.

Throughout the fieldwork Ardian adopts similar identity strategies, yet an incident recounted by Ardian to Christos demonstrates the fragility of such practices. During the fieldwork children were often asked what makes them angry, happy or sad, as a way of assessing the extent to which relationships with public life are emotionally mediated. In response to this question Ardian told Christos a Christmas tale. It is a widespread practice at Christmas for children in Greece to go around their neighbourhoods singing a traditional Christmas carol and collecting money that is often used for personal spending. While doing the neighbourhood rounds with his brother, a woman tells his brother that 'if he wished to sing carols he should first change his foreign name into a Greek one' and that they 'are not Christians' therefore not entitled to sing carols. The incident made Ardian angry. He talked about 'hating them' (the shop owners), using hyperbolic language in the name of justice: 'if he had a knife he would have stabbed her'. He 
describes the event to Christos as very painful not only for himself and his brother but for his entire family.

Ardian's analysis of the event further demonstrates the fragility of practices of transnational identity formation and the ongoing negotiations for belonging that it entails. He tells Christos that he and his family 'are more Christians than her because they do not hate other people'. In a different discussion Ardian further bolsters his social position through reference to another stigmatised 'other' in Greek society, the Roma. This is not a group he has any personal experience of, but he nevertheless mobilises powerful negative social representations of the Roma by referring to them as Jiftes, the Albanian word for Gypsy, and calling them 'black', while also invoking olfactory representations of odour and dirty, as well as practices of dishonesty to further describe them. He says that they have settled in the nearby park thus preventing him from playing soccer. When asked what changes he would make in his neighbourhood he answers: 'He would not want Jiftes to come to their house because sometimes there is such bad smell that they can hardly breathe'. He then goes on to associate this dirt from car exhaust pipes but when probed further he accuses the Jiftes of having stolen his uncle's car battery. At the same time, and in line with the contradictory nature of racist discourses, when asked what makes him sad, Ardian replies that the Gypsy children next to the church of his neighbourhood 'have nothing to eat'.

How does Ardian use the above material and cultural resources available to him to negotiate, construct and reconstruct identity and belonging in precarious economic times? Ardian on many occasions identifies with his Albanian identity, and at times he 
prioritizes this identity. In telling Christos a story about a woman who was claiming to be Greek, while she was Albanian, he was bitterly critical of her, as he found it wrong to conceal one's identity. When he talks about being Albanian he uses the first-person plural. In a story he shared with Christos, he explained how a fast-food restaurant owner had once given him fries for free; he continued his story to identify the restaurant owner as 'naturally an Albanian' corroborating ties with one of his communities. Ardian often engages in discursive practices that positively evaluate his Albanian identity. He talks about a champion wrestler and triumphantly declares that he is 'Albanian like us!'. He also proudly recounts that 'the Albanians helped the Greeks to defeat the Italians in the war. They did so 45 times. And Italy called Germany for support, because everybody feared Germany since they had a larger army. But, still we won'. It is unclear whether the 'we' refers solely to the Albanians or an Albanian-Greek coalition where, however, Albanians are the strong partner.

Ardian, who has not yet studied history at school, imaginatively distorts official history in the above narration since Albania was Italy's ally during the WWII. His understanding of the historical incident must have been constructed on the basis narratives and celebrations of Greece's entry into the World War II at school, which takes the Greek-Italian declaration of war as a key historical moment. The narrative here tends to focus on the heroic stance of a small nation in the face of a much larger and more potent army. Albania does not figure in official histories narrated in such occasions. Ardian fills in the missing information by constructing his own version, whereby the role 
of the 'good' and the 'brave' is attributed to the Albanians; by inventing an AlbanianGreek coalition he fashions a new, possible self.

Ardian regularly comments on social and class differences being fully aware of the family's tight finances. He talks about a Romanian friend who left for Belgium and who is very rich and could hold a disco party for her birthday; he describes 'rich children' as 'being able to travel abroad' and he wishes that he could travel to America, which he regards as a land of affluence, where 'they have tablet-watches and huge tablets' and the land of the mighty where 'there exist big skyscrapers'. He is also aware of other, more affluent childhoods: among his favourite films are the Home Alone series, about which he talked extensively with Christos, describing the world of wealth in which the lead character lived, as well as his inventiveness and independence -but he commented that only rich children can have this. He also likes 'big cars and big motorbikes' -goods that are well beyond the family's means.

The fantasy world of affluence contrasts with the restricted finances of his family. Ardian not only adapts his wishes to the family's limited means but he contributes actively to his household. He helps with everyday housework; and he gave the money he collected from the Christmas carols to his parents to buy furniture for his and his brother's room instead of spending it on toys. In the summer of 2015, an opportunity arose for his family to move flats, moving into a bigger flat in their building while keeping the same rent, on the condition that they renovate the flat themselves. Ardian's father, having manual skills, suggested that they could do it over the summer. However, this meant that they had to forego their much-awaited vacation in Albania, spending their 
holiday money and time for the renovation work instead. Although Ardian was disappointed not to be able to travel to Albania, he gladly helped his mother, father and brother with light work such as cleaning and painting and he spoke of that period fondly, as being a time when he felt very close to his family and during which he contributed significantly to a joint project. Assuming a grown-up role at this early age places him in a diametrically different position to many middle-class children, as well as to received wisdom about childhood as a time free from financial or other obligations in which children focus on educational attainment alone. In immigrant Albanian families, informal, temporary or more permanent forms of children's work, are quite common, putting Albanian families in similar fortunes to those of other (Greek) poor and lower income families. While this is the result of restricted finances (even more so in the current economic crisis) it is also a function of the culture of origin and the traditional agricultural background many immigrants come from (Athanasopoulou, 2013).

\section{Concluding Reflections: Steps Towards an Interdisciplinary Approach of (Trans)National Identity}

In this paper, drawing on a grounded methodology and insights from the sociology of childhood, we set off to explore one child's everyday (trans)national identity practices. National identity is acquired in early childhood (Ricke, 2017), the salience of 'the national' changes over time, as well as the changes themselves, vary considerably across 
different groups of children and across national borders (Barrett, 2000; 2005). In line with the idea that the nation and its symbols are not natural entities or merely cognitive structures (Fox and Miller-Idriss, 2008), this paper has taken a bottom-up, grounded approach to analyzing the way national belonging is part of the contextual, spatial and temporal rhythms of everyday life. We based our analysis on a single ethnographic biography of Ardian, a second-generation migrant child of Albanian origin, living in Athens. Taking our cue from sociological theories of childhood (James, Jenks and Prout, 1998), we have put Ardian's experience at the centre of the analysis, exploring his ecological niche and everyday life, as well as his relationships to people and places, as these unfold at a socio-economic juncture of 'crisis'. In this final section of the paper we think about how interdisciplinary theorizing on national belonging can further support the understanding of children's (trans)national identity practices (Ricke, 2017).

Following Anderson's (1983) notion of a/the nation as an imagined community, national identities are seen as 'produced, reproduced, as well as transformed and dismantled discursively' within everyday social life (Wodak et al., 2009:3). Rather than being passively socialized, people actively and relationally, negotiate, construct and reconstruct explanations and stories that locate them in a social, cultural and historical context (Haste, 2004) changing their practices and/or adopting new ones as relevant. As such, social conditions, narratives and practices are dialectically and dynamically interrelated in the formation of (trans)national identities.

The creative and dynamic interrelated processes and practices of personal engagement in public narratives, and the inverse of making of private stories public, is 
also revealed in children's identity practices (Gardner, 2012; Sirin and Fine 2007;

Katsiaficas et al., 2011). As the case analysis of Ardian demonstrates, children may incorporate the narratives of their culture into their everyday lives and on the basis of this incorporation construct an 'identity narrative'. In this paper, we have, however, demonstrated the contradictions, inventiveness, and fragility of such identity narratives. Drawing from narratives that circulate in his societies and sub-cultures, and using the cultural resources available to him, Ardian negotiated, constructed, and recreated what national belonging and citizenship meant to him. We found that Ardian held on firmly to both country discourses of national identity which he performed in conversation with Christos. Our findings echo those of Koh (2010) whose research has shown that children not only engage with the available tropes and main protagonists of national narratives, but also create their own stories about national identity; as did, for example, Ardian when he re-told the story of a major historical event he was aware of but for which he did not fully know the historical details. As underlined by Hengst (1997) children may be much less restricted, far more playful and resourceful than the adults in creating their own stories. Ardian's version of World War II and of a Greek-Albanian alliance against the Italians can be seen as an example of this.

In sum, our analysis, has attempted to closely look at a migrant child's experiences of encountering, negotiating and practising belonging. It demonstrated the everyday subtle and sophisticated understanding of the complexities and contradictions of national identity in Greece, and one child's own positioning within that at the same time as his own identity was transnationally informed. The paper has explored the panoply of 
strategies and tactics Adrian deployed in making connections, negotiating and establishing his belonging in ways that are protective of his own hyphenation (Sirin and Fine, 2007) as well as the contradictions of Greek identity.

The ethnographic biography demonstrates that national identity formation is an ongoing conversation and embodied practice that children have with themselves, with their close relations (friends and family) and their broader environment (the city), through which they invent idioms of both pleasure and pain. Looking at the migrant experience from a child's perspective we learn that other stories of transnational belonging are possible and actually exist in everyday life. Ardian's narrative reveals his subjective sense and practices of belonging and the ongoing and dynamic processes of negotiating, constructing and reconstructing his (trans)national identity in his everyday life (Ricke, 2017; Sutton, 2010). While he engages in the project of constructing his identity in a context of hyphenation, he masterfully enlists various discursive and non-discursive agents rooted in different aspects of the transnational social field to narrate himself to the researcher (Levitt and Glick Schiller, 2004).

Ardian produces a rich narrative, interlacing cognitive, sensual and emotional elements, that figure identification with those discriminated against and active distancing from those that harass him and his family; a sense of belonging to the Greek culture which he is part of; longing for his village; ambivalences about matters of race and ethnicity; stereotypes of groups that are of lower status than his; heroes who share his Albanian identity; symbols of power; and evaluations and feelings all merge together. And this singular, imaginative, playful and embodied process may well simultaneously 
be a valuable addition and critique to social sciences theorising of how (trans)national identities and belonging emerge in practice.

\section{Acknowledgements}

The research was funded by the European Research Council Starting Grant (ERC-StG335514) to Sevasti-Melissa Nolas. The research in Athens was managed by Christos Varvantakis who also carried out all the fieldwork. Nelly Askouni and Thalia Dragonas are study advisors who contributed to the analysis presented in this paper. We would also like to thank our two anonymous reviewers for the generous, insightful, and timely feedback.

\section{References Cited}

Adamczyk, A. 2016. 'Albanian Immigrants in Greece: From Unwanted to Tolerated?' Journal of Liberty and International Affairs 2(1): 49-59.

Anderson, B. 1983. Imagined Communities. London and New York: Verso.

Athanasopoulou, A. 2013. 'Family Debts, Personal Desires and Migratory Realities: Albanian Second- Generation Youth in Athens.' International Migration 51(2): 127-147. 
Barrett, M. 2005. 'Children's understanding of, and feelings about, countries and national groups'. In Barrett, M. and Buchanan-Barrow, E. (Eds.), Children's understanding of society Hove: Psychology Press; 251-285.

Barrett, M. 2000. The Development of National Identity in Childhood and Adolescence. Inaugural Lecture presented at the University of Surrey (22/03/2000). Available online at http://epubs.surrey.ac.uk/1642/1/00 Inaugural lecture.pdf. Accessed 26/09/2017.

Barrett, M. and Oppenheimer, L. 2011. 'Findings, Theories and Methods in the Study of Children's National Identifications and National Attitudes.' European Journal of Developmental Psychology 8(1): 5-24.

Behar, R. 1993. Translated Woman: Crossing the Border with Esperanza's Story. Boston: Beacon Press.

Benei, V. 2008. Schooling Passions: Nation, History and Language in Contemporary Western India. Stanford, California: Stanford University Press.

Bronfenbrenner, U. 1979. The ecology of human development. Cambridge, MA: Harvard University Press.

Cena, E., Heim, D. and Trandafoiu, R. 2018. 'Changing places: children of return 
migrants in Albania and their quest to belong,' Journal of Ethnic and Migration Studies, 44(7): 1156-1176.

Chatzidaki, A. and Maligkoudi, C. 2013. "Family Language Policies among Albanian Immigrants in Greece," International Journal of Bilingual Education and Bilingualism 16(6): 675-89.

Cheney, K. E. 2007. Pillars of the Nation. Child Citizens and Ugandan National Development. Chicago and London: University of Chicago Press.

Christensen, P. and Prout, A. 2005. 'Anthropological and sociological perspectives on the study of children'. In (eds) Greene, S. and Hogan, D. Researching children's experience: Approaches and Methods. London: Sage; 42-60.

De Certeau, M. 1984. The Practice of Everyday Life. Berkley, California: California University Press.

Dicks, B. Soyinka, B. and Coffey, A. 2006. 'Multimodal Ethnography.' Qualitative Research 6(1): 77-96.

Dobson, M. E. 2009. 'Unpacking Children in Migration Research.' Children's Geographies 7(3): 355-60. 
Dragonas, T. 2013. 'Multiculturalism: Psychosocial processes and politics of identity.'

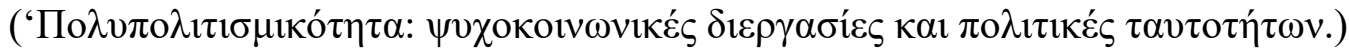

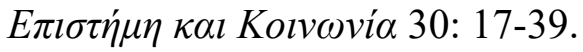

Dragonas, T. 2014. 'The vicissitudes of identity in a divided society: The case of the Muslim Minority in Western Thrace.' In K. Featherstone (Ed.) Europe in Modern Greek History. London: Hurst and Company; 135-152.

Fechter, A-M. and Korpela, M. 2016. 'Interrogating child migrants or 'Third Culture Kids' in Asia: an introduction', Asian and Pacific Migration Journal, 25 (4): 422-428.

Fechter, A-M. 2007. Transnational lives: expatriates in Indonesia. Ashgate: Farnham, UK.

Flyvbjerg, B. 2001. Making Social Science Matter: Why social inquiry fails and how it can succeed again. Cambridge: Cambridge University Press.

Fox, E. J. and Miller-Idriss, C. 2008. 'Everyday nationhood'. Ethnicities 8 (4): 536-563. 
Frangoudaki, A. and Dragona, T. (eds.) 1997. “What is our Country?” Ethnocentrism in Education. [«Tl $\left.\varepsilon i v^{\prime} \nmid \eta \pi \alpha \tau \rho i \delta \alpha \mu \alpha \varsigma ; » E \theta v o \kappa \varepsilon v \tau \rho \imath \sigma \mu o ́ \varsigma \sigma \tau \eta v \varepsilon \kappa \pi \alpha i \delta \varepsilon v \sigma \eta\right]$ Athens: Alexandria.

Frosh, S., Phoenix, A. and Pattman, R. 2003. 'Taking a stand: using psychoanalysis to explore the positioning of subjects in discourse.' British Journal of Social Psychology 42: 39-53.

Gardner, K. 2012. 'Transnational Migration and the Study of Children: An Introduction.' Journal of Ethnic and Migration Studies 38(6): 889-912.

Gardner, K. and Mand, K. 2012. “"My Away Is Here’: Place, Emplacement and Mobility amongst British Bengali Children.” Journal of Ethnic and Migration Studies 38(6): 96986.

Gogonas, N. 2009. 'Language Shift in Second Generation Albanian Immigrants in Greece.' Journal of Multilingual and Multicultural Development 30(2): 95-110.

Haikkola, L. 2011. 'Making Connections: Second-Generation Children and the Transnational Field of Relations.' Journal of Ethnic and Migration Studies 37(8): 120117. 
Hall, K. D. 1995. “'There's a Time to Act English and a Time to Act Indian': The Politics of Identity Among Sikh Adolescents in England." In S. Stephens (ed.) Children and the politics of culture. Princeton NJ: Princeton University Press; 243-264.

Hall, S. 1993. 'Culture, community, nation.' Cultural Studies 7(3): 349-363.

Haste, H. 2004. 'Constructing the Citizen' Political Psychology 25 (3): 413-439.

Hengst, H. 1997. 'Negotiating 'us' and 'them': Children's constructions of collective identity." Childhood 4(1): 43-62.

Herzfeld, M. 1998. Portrait of a Greek Imagination: An Ethnographic Biography of Andreas Nenedakis. University of Chicago Press.

Hirschfeld, L. A. 2002. 'Why don't Anthropologists like Children?' American Anthropologist 104(2): 611-627.

Jackson, M. 2008. 'Between biography and ethnography', The Harvard Theological Review 101(3-4): 377-397.

James, A., Jenks, C. and Prout, A. 1998. Theorizing Childhood. Cambridge: Polity Press. 
Katartzi, E. 2017. 'Young Migrants' Narratives of Collective Identifications and Belonging.' Childhood. Online First. Retrieved September 15, 2017 (https://doi.org/10.1177/0907568217729191).

Katsiaficas, D., Futch, V. A., Fine, M. and Sirin, S. A. 2011. 'Everyday hyphens: Exploring youth identities with methodological and analytic pluralism.' Qualitative Research in Psychology 8(2): 120-139.

Koh, S. S. 2010. National identity and young children: A comparative study of 4th and 5th graders in Singapore and the United States. Ph.D Dissertation, University of Michigan, Michigan.

Kyriazi, A. 2016. 'Ultranationalist discourses of exclusion: a comparison between the Hungarian Jobbik and the Greek Golden Dawn.' Journal of Ethnic and Migration Studies $42(15)$ 2528-2547.

Leonard, M. 2012. 'Us and Them: Young People's Constructions of National Identity in Cyprus.' Childhood 19(4): 467-80.

LeVine, R. A. 2007. 'Ethnographic studies of childhood: A historical overview.' American Anthropologist 109: 247-260. 
Levitt, P. and Glick Schiller, N. 2004. 'Conceptualizing simultaneity: a transnational social field perspective on society.' International Migration Review 38(3): 1002-39.

Lutz, C. 2017. 'What Matters.' Cultural Anthropology 32(2): 181-91.

Mattoni, A. and Vogiatzoglou, M. 2014. 'Italy and Greece, before and after the crisis: between mobilization and resistance against precarity', Quaderni, 84: 57-71.

Mertan, B. 2011. 'Children's perception of national identity and in-group/ out-group attitudes: Turkish-Cypriot school children.’ European Journal of Developmental Psychology 8(1), 74-86.

Michail, D. and Christou, A. 2016. 'Diasporic Youth Identities of Uncertainty and Hope: Second-Generation Albanian Experiences of Transnational Mobility in an Era of Economic Crisis in Greece.' Journal of Youth Studies 19(7): 957-72.

Morrow, V. 1999. “We are people too': Children's and young people's perspectives on children's rights and decision-making in England." The International Journal of Children's Rights 7(2): 149-170. 
Murphy, A. 2018. 'Charting the Emergence of National Identity in Children in Wales', Children \& Society 32(4): 301-313.

Nielsen, H.B. 2016. 'The Arrow of Time in the Space of the Present: Temporality as Methodological and Theoretical Dimension in Child Research', Children \& Society, 30(1), pp. 1-11.

Nolas, S-M. 2015. 'Children's Participation, Childhood Publics and Social Change: A Review', Children \& Society 29(2): 157-167.

Nolas, S-M., Varvantakis, C. and Aruldoss, V. 2016. '(Im)possible Conversations? Activism, Childhood and Everyday Life.' Journal of Social and Political Psychology 4(1): 252-265.

Nolas, S-M., Varvantakis, C. and Aruldoss, V. 2017. 'Talking politics in everyday family life', Contemporary Social Science, 12(1): 68-83.

Nolas, S-M. and Varvantakis, C. (under review) 'Metaphors we experiment with in multimodal ethnography.' Submitted in International Journal of Social Research Methodology. 
Pink, S. 2006. The Future of Visual Anthropology: Engaging the Senses. New York: Routledge.

Pugh, A. J. 2013. 'The theoretical costs of ignoring childhood: rethinking independence, insecurity, and inequality.' Theory and Society 43: 71-89.

Punch, S. 2012. 'Studying Transnational Children: A Multi-Sited, Longitudinal, Ethnographic Approach.' Journal of Ethnic and Migration Studies 38(6): 1007-23.

Ricke, A. 2017. 'Making “Sense” of Identity.' Journal of Contemporary Ethnography 46(2): 173-202.

Sayer, A. 2011. Why things matter to people: Social science, values and ethical life. Cambridge: Cambridge University Press.

Scourfield, J., Dicks, B., Drakeford, M. and Davies, A. 2006. Children, Place and Identity. Nation and locality in middle childhood. New York: Routledge.

Sirin, S. R. and Fine, M. 2007. 'Hyphenated Selves : Muslim American Youth Negotiating Identities on the Fault Lines of Global Conflict.' Applied Development Science 11(3): 151-163. 
Spyrou, S. 2002. "Images of 'the Other': 'the Turk' in Greek Cypriot Children's Imaginations." Race Ethnicity and Education (5) 3: 255 - 272.

Sutton, D. E. 2010. 'Food and the Senses.' Annual Review of Anthropology 39(1): 20923.

Tilly, C. 2011. 'The Impact of the Economic Crisis on International Migration: A Review.' Work, employment and society 25(4):675-92.

Triandafyllidou, A. and Kokkali, I. 2010. 'Background Report: Accept Pluralism. Tolerance and cultural diversity discourses in Greece.' Robert Schumann Centre for Advanced Studies, European University Institute. Available online at http://cadmus.eui.eu/handle/1814/19781. Last accesed 15/09/2017.

Varvantakis, C. (under review) 'Acropolis, from a distance: Distance, Proximity and Haptic Photography in a Research with Children in Athens.' Submitted in Visual Studies.

White, A., Ní Laoire, C., Tyrrell, N., and Carpena-Méndez, F. 2011. ‘Children's Roles in Transnational Migration.' Journal of Ethnic and Migration Studies 37(8): 1159-70.

Whyte, W- F. 1943. Street Corner Society. Chicago: University of Chicago Press. 
Wodak, R., de Cilia, R., Reisigl, M. and Liebhart, K. (Eds)(2009) The discursive construction of national identity. Transl. A. Hirsch, R. Mitten and J.W. Unger, $2^{\text {nd }}$ edition. Edinburgh: Edinburgh University Press.

Yiakoumaki, V. 2006. “'Local,' 'Ethnic,' and 'Rural' Food: On the Emergence of 'Cultural Diversity' in Greece since Its Integration in the European Union.” Journal of Modern Greek Studies 24(2): 415-445.

Zeitlyn, B. 2012. 'Maintaining Transnational Social Fields: The Role of Visits to Bangladesh for British Bangladeshi Children.' Journal of Ethnic and Migration Studies 38(6): 953-68.

Zeitlyn, B. and Mand, K. 2012. 'Researching Transnational Childhoods.' Journal of Ethnic and Migration Studies 38(6): 987-1006. 